\title{
UNDERSTANDING STUDENT PERFORMANCE IN AN INTRODUCTORY INFORMATION SYSTEMS COURSE: AN ASSESSMENT FOR ABET
}

\author{
Sushma Mishra, Robert Morris University, Mishra@rmu.edu \\ Linda Kavanaugh, Robert Morris University, Kavanaugh@rmu.edu \\ John Turchek, Robert Morris University, Turchek@rmu.edu
}

\begin{abstract}
Assessment of course outcomes is an important aspect of ensuring that educational institutions deliver quality and relevant education to students. Accreditation adds value to a collegiate program and ensures that it has met standards necessary to produce graduates who would have better opportunities in employment, mobility and providing positive impact on society (abet.org). Approximately 85,000 students graduate from ABET-accredited programs each year (abet.org). This paper explores the process of assessing course outcome for an introductory information systems course. The methodology is discussed, recommendations are provided, and a conclusion is presented.
\end{abstract}

Keywords: Course outcomes, assessment, ABET, information systems, accreditation

\section{INTRODUCTION}

Institutions of higher education are under pressure in recent years to graduate students with better communication, thinking, and teamwork skills [2]. Industry surveys indicate that college graduates should have soft skills such as written communications, analytical/critical thinking, oral communications, computing technology, teamwork, etc. [3]. Accreditation bodies require colleges to assess student learning directly through the use of exams, projects, and written papers. While faculty generally agree that these skills are important, it is often difficult to find time in courses to explicitly teach and assess these skills.

In the past decade, accrediting bodies have changed assessment from a stand-alone one time activity to a continuous one [1]. In this new culture of assessment, an institution has to demonstrate a culture of continuous assessment as an ongoing process [6]. It is important now that programs not only present assessment results to the agencies but also show how it has initiated improvements based on the results they obtained from such activities. Accrediting agencies have also transformed assessment from an occasional activity to a continuous one. In the past, a program needed to reflect on its effectiveness only when each accreditation review approached, an event that might occur as infrequently as every ten years. Now, a program must create a culture of assessment in which assessment is an ongoing activity. Further, the program must not only present assessment results to the accrediting agencies but also show that it has initiated improvements in response to what the results disclose [8]. This makes sense in an everchanging field such as information systems.

The course in discussion here, INFS 1020, is a university-wide core course and is usually taken by students in freshmen year. It includes topics such as hardware and software, operating systems, systems development, database, networking and information security. However important these concepts might be to an upcoming graduate, the relevance of learning these topics is not so obvious to the students. This has been the case with introductory MIS courses at other schools as well. Aytes (2004) notes that for a core MIS course students do not readily recognize the value that information plays in integrating business functions. They feel that they need additional help in learning to use technology, rather than an overview of conceptual concepts. The content of this course has always been a point of discussion in the department and the school. 


\section{Issues in Information Systems}

Volume 13, Issue 1, pp. 331-339, 2012

A description of the course is as follows:

INFS1020 - Introduction to Decision Support Systems provides the student with an understanding of computers, essential computer hardware and software, and the impact of information technology on organizations and society. The complexity of designing effective information systems is discussed, and the student learns to compare, analyze, and evaluate information from various systems. The course involves both an overview of technological concepts and student practice in solving typical information-related problems. The importance of logical reasoning and solving specific technical problems is addressed by developing structured logic combined with software. Course also includes Excel and Access software.

Our BS in Computer Information Systems degree and our BS Information Science degree are both accredited by ABET-CAC. Earning a degree is a significant achievement and an important investment in a student's future. Since so much of their future success depends on their educational foundation, the quality of the education they receive makes a big difference. ABET-accredited programs such as we have at Robert Morris assure prospective students a quality education and an enhanced employment opportunity. (http://www.abet.org/accrediatation-matters-students). Because of this accreditation, we are very concerned about assessment of all INFS courses especially in INFS1020 because it is in the RMU Core and its regular assessment is very important to meet Middle States Association of Colleges and Schools Regional Accreditation criteria.

The rest of the paper is organized as following. The next section of the paper talks about assessment in general. There are different types of assessments and this section provides a detailed overview of theses available assessment approaches. Following a discussion on assessment, the methodology applied for assessing this particular course is described along with the data collection for assessment. The section following the methodology description presents the results of data analysis from the academic year 2010-2011. The discussion and recommendation section presents the insights from this assessment exercise. The recommendations are based on our experiences with this core introductory-level IS course. Finally the conclusion section presents a summary of the paper.

\section{ASSESSMENT OF COURSES}

Assessment is often equated and confused with evaluation, but the two concepts are different. Assessment is used to determine what a student knows or can do, while evaluation is used to determine the worth or vales of a course or program [12].

There are many other definitions of assessment, too. The definition we used is the following:

Assessment is an ongoing process aimed at understanding and improving student learning. It involves making our expectations explicit and public; setting appropriate criteria and high standards for learning quality; systematically gathering, analyzing, and interpreting evidence to determine how well performance matches those expectations and standards; and using the resulting information to document, explain, and improve performance. When it is embedded effectively within larger institutional systems, assessment can help us focus our collective attention, examine our assumptions, and create a shared academic culture dedicated to assuring and improving the quality of higher education [4].

\section{Purpose of Assessment}

The purpose of assessment is to support data-driven decision-making and measure knowledge, skills, or abilities against defined competencies or learning outcomes. Assessments associated with the learning process are often classified as diagnostic, formative, needs, reactive, or summative.

Diagnostic assessments are primarily used to identify needs and to determine prior knowledge of individual participants. Diagnostic assessments usually occur prior to a learning experience. These are often known as "placement tests" or "placement exams." 


\section{Issues in Information Systems}

Volume 13, Issue 1, pp. 331-339, 2012

Formative assessment has the primary objective of providing prescriptive feedback to a student to inform next steps in the instructional process. Educators tend to use quizzes in this fashion.

Needs assessment is used to determine the knowledge, skills, abilities and attitudes of a group to assist with gap analysis and courseware development. Gap analysis determines the variance between what a student knows and what they are required to know. This too is a diagnostic tool, but it is used in the context of performance improvement in a workplace.

Reaction assessment takes place after a course or learning experience to gather the students' opinions. Reaction assessments are often known as "smile sheets," "level 1 surveys" or "course evaluations."

Summative assessment is where the primary purpose is to give a quantitative grading and make a judgment about the participant's achievement. Summative assessments typically take place at the end of a course of instruction where the goal is to provide overall information on the amount and quality of student learning. These are often known as "mid-term exams" or "final exams." [5]

\section{Types of Assessments}

There are a number of types of assessments, each of which is appropriate for different assessment purposes or goals. When deciding the type of assessment to use, first consider the purpose of the assessment. Is it for diagnostic or placement purposes? Is it to provide feedback throughout the learning process? Is it to determine at the end of a course of study if a student has mastered skills defined in a set of standards? Is it to determine the gap between what students know and what they need to know? Is it to determine student opinions? Depending on the purpose of the assessment, different types of assessments may be utilized [5].

Table 1: Types of assessment

\begin{tabular}{|l|l|l|l|}
\hline $\begin{array}{l}\text { Type of } \\
\text { Assessment }\end{array}$ & Definition & Purpose & Examples \\
\hline Performance & $\begin{array}{l}\text { A stimulus or prompt designed to elicit a } \\
\text { performance from a student to } \\
\text { demonstrate knowledge, skills, and } \\
\text { abilities related to a specific problem- } \\
\text { solving activity in a specific context. }\end{array}$ & $\begin{array}{l}\text { Needs } \\
\text { Diagnostic } \\
\text { Formative } \\
\text { Summative }\end{array}$ & $\begin{array}{l}\text { 1. Use appropriate tools in an automotive } \\
\text { skills class to fix a mechanical problem } \\
\text { with an engine. 2. Class assignment. 3. } \\
\text { Tutorial. 4. Interviews. 5. Peer reviews. }\end{array}$ \\
\hline Portfolio & $\begin{array}{l}\text { Systematic collections of work products } \\
\text { that are typically collected over time. May } \\
\text { contain assessment scores, work artifacts, } \\
\text { student journals or notes. }\end{array}$ & $\begin{array}{l}\text { Formative } \\
\text { Summative }\end{array}$ & $\begin{array}{l}\text { 1. Course portfolio. 2. College portfolio. } \\
\text { 3. Student portfolio. 4. Journals. }\end{array}$ \\
\hline Production & $\begin{array}{l}\text { A stimulus or prompt designed to have a } \\
\text { student produce a work artifact to } \\
\text { demonstrate knowledge, skills, and } \\
\text { abilities related to a specific problem- } \\
\text { solving activity in a specific context. }\end{array}$ & $\begin{array}{l}\text { Needs } \\
\text { Diagnostic } \\
\text { Formative } \\
\text { Summative }\end{array}$ & $\begin{array}{l}\text { 1. Produce an Excel spreadsheet in an } \\
\text { accounting class to demonstrate mastery } \\
\text { of accounting practices. 2. Class } \\
\text { assignment. 3. Tutorial. 4. Essay test. 5. } \\
\text { Speaking test. }\end{array}$ \\
& $\begin{array}{l}\text { A set of questions designed to elicit } \\
\text { student opinions about the learning } \\
\text { environment }\end{array}$ & $\begin{array}{l}\text { Reaction } \\
\text { Needs }\end{array}$ & $\begin{array}{l}\text { 1. Course or instructor evaluation. 2. } \\
\text { Survey of student services. 3. Survey of } \\
\text { student satisfaction. 4. Focus groups. }\end{array}$ \\
\hline Survey & \multicolumn{3}{|l}{} \\
\hline
\end{tabular}




\section{Issues in Information Systems}

Volume 13, Issue 1, pp. 331-339, 2012

\begin{tabular}{|c|c|c|c|}
\hline Quiz & $\begin{array}{l}\text { A set of questions used to measure a } \\
\text { student's knowledge or skills for the } \\
\text { purpose of providing feedback to inform } \\
\text { the student and the teacher of the current } \\
\text { level of knowledge or skill. }\end{array}$ & Formative & $\begin{array}{l}\text { 1. Informal, in-course set of questions to } \\
\text { determine if students are tracking with the } \\
\text { content or if misconceptions are } \\
\text { developing. Useful for determining next } \\
\text { events in learning process. 2. Class } \\
\text { assignment. 3. Tutorial. 4. Case study. }\end{array}$ \\
\hline Test & $\begin{array}{l}\text { A method for determining student } \\
\text { learning at defined intervals before, } \\
\text { within or after a course of study to } \\
\text { determine if students are ready for the } \\
\text { next stage of instruction. }\end{array}$ & $\begin{array}{l}\text { Needs } \\
\text { Diagnostic } \\
\text { Summative }\end{array}$ & $\begin{array}{l}\text { 1. Placement test or pretest before a } \\
\text { course starts. } 2 \text {. Mid-term. } 3 \text {. Final test in } \\
\text { a course. } 4 \text {. Case study. }\end{array}$ \\
\hline Exam & $\begin{array}{l}\text { A method for determining whether } \\
\text { student learning meets criteria established } \\
\text { by an external source. }\end{array}$ & Summative & $\begin{array}{l}\text { 1. Certification exam where a cut-score } \\
\text { must be achieved before the student may } \\
\text { be certified or licensed in a field. Job } \\
\text { placement exam, where a cut-score must } \\
\text { be obtained before a job will be offered. }\end{array}$ \\
\hline
\end{tabular}

\section{METHODOLOGY}

We mapped the course objectives of this course with the performance indicators established by the department to assess the performance of students for this required 1000 level introductory IS course. Majority of the students in this course are freshmen (more than 90\%) and this is a required course. In any typical semester, between 200 and 250 students take this course. For this assessment, we collected 150 responses. Several sections of this course are offered and many of these are taught by part-time faculty.

The table below lists the performance indicators established to assess the student performance in this course.

Table 2: Performance Indicators for INFS 1020

\begin{tabular}{|l|l|}
\hline 1 & $\begin{array}{l}\text { Establish a firm foundation in information systems on which students can build successful careers in an area of } \\
\text { expertise of their choice. }\end{array}$ \\
\hline 2 & Identify the key components of information technology equipment. \\
\hline 3 & Understand the difference between computer hardware and software. \\
\hline 4. & Identify the types and purposes of computer software who primary use is in a business environment \\
\hline 5. & $\begin{array}{l}\text { Identify the applicability of the life cycle approach to developing information systems and understand the activities } \\
\text { and expected results of each phase of this process. }\end{array}$ \\
\hline 6. & $\begin{array}{l}\text { Apply microcomputer software and database software to the solution of problems typically encountered at the } \\
\text { various levels of society and organizations. }\end{array}$ \\
\hline 7 & $\begin{array}{l}\text { Understand the encompassing impact of information technology to different aspects of personal, social and cultural } \\
\text { life }\end{array}$ \\
\hline
\end{tabular}

Several learning objectives were established for the students and all the objectives were mapped with our performance indicators for this course for assessment purposes (table 3 below). 


\section{Issues in Information Systems}

Volume 13, Issue 1, pp. 331-339, 2012

Table 3: Mapping of course LEARNING objectives with performance indicator used for assessment

\begin{tabular}{|c|c|}
\hline Course Learning Objectives & $\begin{array}{l}\text { Performance } \\
\text { Indicators } \\
\text { used for } \\
\text { assessment } \\
\text { (Table 1) }\end{array}$ \\
\hline Understand the principles of Information Systems. & 1,2 \\
\hline $\begin{array}{l}\text { Establish a firm foundation in Information Systems on which students can build successful careers in an } \\
\text { area of expertise of their choice. }\end{array}$ & 1,2 \\
\hline $\begin{array}{l}\text { Understand how the major categories of information systems support the information requirements of all } \\
\text { organizations. }\end{array}$ & 6 \\
\hline $\begin{array}{l}\text { Understand the role and applicability of personal information systems, work group systems and enterprise } \\
\text { wide systems in providing the required information. }\end{array}$ & 6 \\
\hline $\begin{array}{l}\text { Understand and apply the concepts of blending technology with the needs of people and the requirements } \\
\text { of an organization and the related concept of putting needs before the technology. }\end{array}$ & 2 \\
\hline $\begin{array}{l}\text { Understand the capabilities of available information systems technology and select appropriate } \\
\text { technology for the addressing of the defined information requirements. }\end{array}$ & 3 \\
\hline $\begin{array}{l}\text { Understand current trends in the evolution of information systems technology and identify the } \\
\text { implications of these trends on the organization's information systems. }\end{array}$ & 4 \\
\hline $\begin{array}{l}\text { Identify the applicability of the life cycle approach to developing information systems and understand the } \\
\text { activities and expected results of each phase of this process. }\end{array}$ & 5 \\
\hline $\begin{array}{l}\text { Identify the role of and understand the activities performed in prototypes and other alternatives to the life } \\
\text { cycle approach to systems development }\end{array}$ & 5 \\
\hline $\begin{array}{l}\text { Identify the applicability of personal information systems and end-user computing, understand the } \\
\text { problems related to these approaches to providing information and the techniques used to evaluate } \\
\text { applicability, select technology and control the implementation and utilization. }\end{array}$ & 4 \\
\hline $\begin{array}{l}\text { Identify ethical, moral and legal issues relating to the storage and dissemination of information and the } \\
\text { use of information systems. }\end{array}$ & 7 \\
\hline $\begin{array}{l}\text { Apply microcomputer software and database software to the solution of problems typically encountered at } \\
\text { the various levels of society and organizations. }\end{array}$ & 6 \\
\hline
\end{tabular}

For the purposes of this research, a survey instrument comprising 50 items was created by the researchers. The items in this survey were mapped to the performance indicators such that we get some understanding of how well are the students performing of several dimensions defined up front. The data from this test was analyzed to assess the performance based on predefined performance indicators. This test was used as final exam by one researcher and as extra credit test for the other researcher. Students took the survey on scantrons and the data was analyzed using Test gen analyzer and exported on SPSS. 


\section{Issues in Information Systems}

Volume 13, Issue 1, pp. 331-339, 2012

Results:

To analyze the performance level of the students in this course, the following rubric was used:

Table 4: Performance assessment rubric

\begin{tabular}{|l|l|}
\hline \multicolumn{1}{|c|}{ Level of Performance } & \multicolumn{1}{|c|}{ Categories of Result } \\
\hline Performance level $<60 \%:$ & Unacceptable \\
\hline Performance level $>60 \%$ and $<70 \%:$ & Satisfactory \\
\hline Performance level $>70 \%$ and $<80 \%:$ & Good \\
\hline Performance level $>80 \%$ and $<90 \%:$ & Excellent \\
\hline Performance level $>90 \%:$ & Outstanding \\
\hline
\end{tabular}

The table below suggests the performance of students based on each performance indicators established for this course.

Table 5: Breakdown of performance indicators (item wise) with the student performance data

\begin{tabular}{|c|c|c|c|c|c|}
\hline \multirow[t]{2}{*}{ Course Objectives/ Performance Indicator } & \multirow[t]{2}{*}{ Items } & \multicolumn{3}{|c|}{ Number of respondents } & \multirow[t]{2}{*}{ Comments } \\
\hline & & Items & $\begin{array}{l}\text { Correct } \\
\text { response }\end{array}$ & $\%$ & \\
\hline \multirow{8}{*}{$\begin{array}{l}\text { Performance Indicator 1: Establish a firm } \\
\text { foundation in information systems on which } \\
\text { students can build successful careers in an } \\
\text { area of expertise of their choice. }\end{array}$} & \multirow[t]{8}{*}{8} & Item 1 & 43 & 93 & \multirow{8}{*}{$\begin{array}{l}\text { Overall performance } \\
\text { averages around } 92 \% \text { - } \\
\text { Outstanding }\end{array}$} \\
\hline & & Item 7 & 45 & 98 & \\
\hline & & Item 12 & 38 & 83 & \\
\hline & & Item 20 & 36 & 78 & \\
\hline & & Item 21 & 43 & 93 & \\
\hline & & Item 23 & 42 & 91 & \\
\hline & & Item 28 & 46 & $\begin{array}{l}10 \\
0\end{array}$ & \\
\hline & & Item 34 & 44 & 96 & \\
\hline \multirow{11}{*}{$\begin{array}{l}\text { Performance Indicator 2: Identify the key } \\
\text { components of information technology } \\
\text { equipment. }\end{array}$} & \multirow[t]{11}{*}{12} & Item 2 & 45 & 98 & \multirow{11}{*}{$\begin{array}{l}\text { Overall performance } \\
\text { averages around } 81 \% \text { - } \\
\text { Excellent }\end{array}$} \\
\hline & & Item 3 & 46 & $\begin{array}{l}10 \\
0 \\
\end{array}$ & \\
\hline & & Item 6 & 40 & 87 & \\
\hline & & Item 11 & 12 & 26 & \\
\hline & & Item 14 & 35 & 76 & \\
\hline & & Item 15 & 27 & 59 & \\
\hline & & Item 17 & 28 & 61 & \\
\hline & & Item 19 & 43 & 93 & \\
\hline & & Item 27 & 45 & 98 & \\
\hline & & Item 30 & 46 & $\begin{array}{l}10 \\
0\end{array}$ & \\
\hline & & Item 36 & 40 & 87 & \\
\hline $\begin{array}{l}\text { Performance Indicator 3: Understand the } \\
\text { difference between computer hardware and }\end{array}$ & 2 & Item 4 & 46 & $\begin{array}{l}10 \\
0\end{array}$ & $\begin{array}{l}\text { Overall performance } \\
\text { averages around } 100 \% \text { - }\end{array}$ \\
\hline
\end{tabular}




\section{Issues in Information Systems}

Volume 13, Issue 1, pp. 331-339, 2012

\begin{tabular}{|c|c|c|c|c|c|}
\hline software. & & Item 5 & 46 & $\begin{array}{l}10 \\
0\end{array}$ & Outstanding \\
\hline \multirow{6}{*}{$\begin{array}{l}\text { Performance Indicator 4: Identify the types } \\
\text { and purposes of computer software who } \\
\text { primary use is in a business environment }\end{array}$} & \multirow[t]{6}{*}{6} & Item 13 & 17 & 37 & \multirow{6}{*}{$\begin{array}{l}\text { Overall performance } \\
\text { averages around } 69 \%- \\
\text { Satisfactory }\end{array}$} \\
\hline & & Item 16 & 43 & 93 & \\
\hline & & Item 18 & 27 & 59 & \\
\hline & & Item 22 & 45 & 98 & \\
\hline & & Item 29 & 20 & 43 & \\
\hline & & Item 35 & 37 & 80 & \\
\hline \multirow{7}{*}{$\begin{array}{l}\text { Performance Indicator 5: Identify the } \\
\text { applicability of the life cycle approach to } \\
\text { developing information systems and } \\
\text { understand the activities and expected results } \\
\text { of each phase of this process. }\end{array}$} & \multirow[t]{7}{*}{7} & Item 37 & 26 & 57 & \multirow{7}{*}{$\begin{array}{l}\text { Overall performance } \\
\text { averages around } 54 \% \text { - } \\
\text { Unacceptable }\end{array}$} \\
\hline & & Item 38 & 27 & 59 & \\
\hline & & Item 39 & 43 & 93 & \\
\hline & & Item 40 & 27 & 59 & \\
\hline & & Item 41 & 4 & 9 & \\
\hline & & Item 42 & 25 & 54 & \\
\hline & & Item 43 & 20 & 43 & \\
\hline \multirow{9}{*}{$\begin{array}{l}\text { Performance Indicator } 6 \text { : Apply } \\
\text { microcomputer software and database } \\
\text { software to the solution of problems typically } \\
\text { encountered at the various levels of society } \\
\text { and organizations. }\end{array}$} & \multirow[t]{9}{*}{10} & Item 31 & 40 & 87 & \multirow{9}{*}{$\begin{array}{l}\text { Overall performance } \\
\text { averages around } 69 \% \text { - } \\
\text { Satisfactory }\end{array}$} \\
\hline & & Item 32 & 45 & 98 & \\
\hline & & Item 33 & 38 & 83 & \\
\hline & & Item 45 & 29 & 63 & \\
\hline & & Item 46 & 20 & 43 & \\
\hline & & Item 47 & 24 & 52 & \\
\hline & & Item 48 & 37 & 80 & \\
\hline & & Item 49 & 25 & 54 & \\
\hline & & Item 50 & 27 & 59 & \\
\hline \multirow{5}{*}{$\begin{array}{l}\text { Performance Indicator 7: Understand the } \\
\text { encompassing impact of information } \\
\text { technology to different aspects of personal, } \\
\text { social and cultural life }\end{array}$} & \multirow[t]{5}{*}{5} & Item 8 & 36 & 78 & \multirow{5}{*}{$\begin{array}{l}\text { Overall performance } \\
\text { averages around } 94 \% \text { - } \\
\text { Outstanding }\end{array}$} \\
\hline & & Item 9 & 43 & 93 & \\
\hline & & Item 10 & 46 & $\begin{array}{l}10 \\
0\end{array}$ & \\
\hline & & Item 24 & 45 & 98 & \\
\hline & & Item 25 & 45 & 98 & \\
\hline
\end{tabular}

\section{DISCUSSIONS AND RECOMMENDATIONS}

This course is targeted at freshmen level students and is required by all the students in the University. An acceptable performance level for this course has been estimated at $70 \%$. The course assessment results suggest there are several areas in this course where students are doing very well. Data for performance indicators 1, 2, 3 and 7 suggest an impressive performance for these dimensions. Data for performance indicators 4 and 6 suggest a good grasp of the concepts under this dimensions and a fair room for improvement. Data for indicator 5 suggests a below average performance on concepts under this dimension. Reasons for poor performance in this area call for further scrutiny. We need to prepare our students in a better way in the above dimension. The overall performance for the course can easily be said to be well beyond our acceptable performance level of $70 \%$.

Along with assessment, this course employed several techniques to engage students in theoretical as well as practical aspects of the content. Thirty percent of the total grade was used towards hands-on exercises and assignments in Excel and Access tools for decision making. Fifty percent of the grade was employed in assessing the depth of theoretical concepts in this course along with the ability to apply the concepts in real life situations. Ten percent of 


\section{Issues in Information Systems}

Volume 13, Issue 1, pp. 331-339, 2012

the grade was for a final group project along with mandatory presentation to the class. This exercise has been beneficial to the students in providing an opportunity to work as a team and also engage an audience in a discussion. Remaining of the grade $(10 \%)$ was awarded for class participation.

Recommendations include the following:

1. We may need to revisit the areas covered in the course. Do students need to know life cycles approach to developing systems (performance was unacceptable)?

2. The concepts considered "satisfactory" should be revisited as to whether we should spend more time on the content or do we not cover that particular subject(s).

3. Ideally, we could have multiple introductory level information systems classes that meet the interests of a variety of students with different learning abilities. This would not only reduce the number of students in the introduction to computer science classes, but this solution might capture the interests students have for computers and computer science.

4. Maybe, a more realistic approach to our situation is to separate the information systems department into theoretical and applied, and therefore, students have a better idea of the type of I/S class they are entering and the material covered. There is a reason why such a variety of people take the introduction to information systems course, and the reason is because the students are intrigued by the subject itself and/or they feel the subject can aid them in their discipline of study. However, instead of seeing a non-I/S student's curiosity for computers being kindled, one tends to see quite the opposite. Very rarely do most of the students who take a traditional introductory-level course take another computing course in the future. (Parham, 2003, page 125)

5. We might also want to "tackle" the problem by trying to decide what "should" be taught in an introductory course rather than trying to "fit" the course to a table of contents in a textbook.

6. The final aim of any assessment process is improving the academic programs being offered by educational institutions. Even though we place great effort in collecting data and creating assessment reports for courses such as INFS 1020 the bigger questions still remains: Are we improving our programs and curriculum based on the results that we get? In other words there is a need to establish a "feedback loop" into our curriculum development process such that the benefits of performing assessments are realized sooner than later. It is imperative that eventually all the assessment efforts result into program improvement and value addition to institutions.

\section{CONCLUSION}

This study presents the assessment results from an introductory IS course at Robert Morris University. The methodology of conducting this assessment along with the results is presented. There are certain areas identified in the curriculum that need more focus on the part of faculty as well as students. Recommendations are provided to identify areas of improvement in the content of the course. Further studies are required to study the impact of recommended changes and use the leanings in the way which is beneficial to the students. 


\section{Issues in Information Systems}

Volume 13, Issue 1, pp. 331-339, 2012

\section{REFERENCES}

1. Anderson, Paul, Benamati, John "Skip", Merhout, Jeffrey W. and Rajkumar, T. M., (2010) "Are Student SelfAssessments a Valid Proxy for Direct Assessments in Information Systems Programs?", AMCIS 2010 Proceedings. Paper 106. http://aisel.aisnet.org/amcis2010/106

2. Aytes, K. (2004). Adding Value to the Core Business Curriculum: Innovative Use of IS Courses, Proceedings of the Tenth Americas Conference on Information Systems, New York, New York, August 2004

3. Albrecht, W. S. and R. J. Sack. (2000). Accounting Education: Charting the Course through a Perilous Future, American Accounting Association. Sarasota, FL

4. Angelo, T. (1995) AAHE Bulletin, November 1995, p.7 Retrieved on 04.30/12 http://aahea.org/bulletins.html

5. Assessment Framework (2004) An Assessment Framework for the Community College, Measuring Student Learning and Achievement as a Means of Demonstrating Institutional Effectiveness, August 2004, Assessment Framework, V 1.-0 Retrieved on 04/30/12 http://www.league.org/publication/whitepapers/0804.html

6. Cooper, G., and Heinze, A. (2007), Centralization of Assessment: Meeting the Challenges of Multi-Year Team Projects in Information Systems Education, Journal of Information Systems Education, 18(3), 345-355

7. Edtech (2012) Retrieved on 04/24/12 (http://www.edtech.vt.edtech/id/assess/assess/html

8. Harper, J. and Harder, J. (2009), Assurance of Learning in the MIS Program. Decision Sciences Journal of InnovativeEducation. 7(2), 489-504

9. Parham, J., (2003). AN ASSESSMENT AND EVALUATION OF COMPUTER SCIENCE EDUCATION, 2003, page 125 Retrieved on 04/30/12 http://www.cs.clemson.edu/-jparham_2003_publication.pdf 